\title{
Health Effects of Resveratrol: Results from Human Intervention Trials
}

\author{
Sonia L. Ramírez-Garza 1,2 , Emily P. Laveriano-Santos 1® , María Marhuenda-Muñoz 1,2, \\ Carolina E. Storniolo 1,2, Anna Tresserra-Rimbau ${ }^{3}$, Anna Vallverdú-Queralt 1,2® \\ and Rosa M. Lamuela-Raventós $1,2, * \mathbb{D}$ \\ 1 Department of Nutrition, Food Science and Gastronomy, School of Pharmacy and Food Sciences XaRTA, \\ Institute of Nutrition and Food Safety (INSA-UB), University of Barcelona, 08921 Santa Coloma de \\ Gramenet, Spain; sonialrmz@gmail.com (S.L.R.-G.); elaversa21@alumnes.ub.edu (E.P.L.-S.); \\ mmarhuendam@ub.edu (M.M.-M.); carolina.e.storniolo@gmail.com (C.E.S.); avallverdu@ub.edu (A.V.-Q.) \\ 2 CIBER Physiopathology of Obesity and Nutrition (CIBEROBN), Institute of Health Carlos III, \\ 28029 Madrid, Spain \\ 3 Human Nutrition Unit, University Hospital of Sant Joan de Reus, Department of Biochemistry and \\ Biotechnology, Faculty of Medicine and Health Sciences, Pere Virgili Health Research Center, University \\ Rovira i Virgili, 43201 Reus, Tarragona, Spain; anna.tresserra@iispv.cat \\ * Correspondence: lamuela@ub.edu; Tel.: +34-934-034-843; Fax: +34-934-035-931
}

Received: 30 October 2018; Accepted: 27 November 2018; Published: 3 December 2018

\begin{abstract}
The effect of resveratrol (RV) intake has been reviewed in several studies performed in humans with different health status. The purpose of this review is to summarize the results of clinical trials of the last decade, in which RV was determined in biological samples such as human plasma, urine, and feces. The topics covered include RV bioavailability, pharmacokinetics, effects on cardiovascular diseases, cognitive diseases, cancer, type 2 diabetes (T2D), oxidative stress, and inflammation states. The overview of the recent research reveals a clear tendency to identify RV in plasma, showing that its supplementation is safe. Furthermore, RV bioavailability depends on several factors such as dose, associated food matrix, or time of ingestion. Notably, enterohepatic recirculation of RV has been observed, and RV is largely excreted in the urine within the first four hours after consumption. Much of the research on RV in the last 10 years has focused on its effects on pathologies related to oxidative stress, inflammatory biomarkers, T2D, cardiovascular diseases, and neurological diseases.
\end{abstract}

Keywords: bioavailability; antioxidant; obesity; metabolic diseases

\section{Introduction}

In the last decades, lifestyle changes, especially in dietary patterns, have been increasingly seen as a means of preventing and treating chronic diseases. In this context, polyphenols have emerged as natural compounds with wide-ranging beneficial effects against cardiovascular diseases (CVD) and cancer [1,2]. Polyphenols are metabolized by the intestine, hepatic cells, or intestinal microbiota. The intestinal absorption, bioavailability, and pharmacokinetics of polyphenols are conditioned by the food matrix in which they are ingested [3,4].

Resveratrol (RV), a naturally occurring polyphenol (trans-3,4',5-trihydroxystilbene), possesses anti-inflammatory, anti-tumorigenic, and antioxidant properties, which may be harnessed in strategies against chronic diseases. The main sources of RV include, above all, grapes (Vitis vinifera L.), a variety of berries, peanuts, medicinal plants such as Japanese knotweed [5], and red wine.

Studies on the health benefits of RV have reported a reduction in age-associated symptoms and the prevention of early mortality in obese animals [6-8]. The life expectancy of some small organisms has 
been extended by RV via the stimulation of caloric restriction [9] and the delay of specific age-related phenotypes, e.g., abnormal glucose metabolism [10]. RV is also associated with a slowing down or prevention of cognitive deterioration [11].

The potential mechanisms of action responsible for the health effects of RV are numerous [5]. As RV triggers the expression of a wide range of antioxidant enzymes, determining the contribution of each mechanism to an overall decrease in oxidative stress is a complex task [12]. Additionally, a large number of receptors, kinases, and other enzymes interact with RV, which may influence its biological effects.

The activities of sirtuin 1 (SIRT1) and adenosine monophosphate-activated protein kinase (AMPK), enzymatic regulators of metabolism in multiple tissues, are stimulated by RV in vivo $[5,13,14]$. Some of the beneficial effects of RV are due to the overexpression of SIRT1 [15]. Moreover, RV has been reported to be a potent inhibitor of quinone reductase 2 activity, which is associated with neurological disorders, although more research is required to confirm this hypothesis [16]. The determination of all effects of $\mathrm{RV}$ in humans remains a major challenge.

After oral ingestion, RV is metabolized in the liver to glucuronide and sulphate forms and in the intestine by hydrogenation of the aliphatic double bond $[17,18]$. RV has been found in urine samples of subjects who have drunk a glass of wine per week or three glasses per week three or five days after the last consumption, respectively [19].

The aim of this review is to summarize the health effects of RV in humans as reported by studies carried out in the last decade, including the determination of plasma, urine, and feces RV and its metabolites. The information is presented in two sections: bioavailability and pharmacokinetics of RV and the effects of RV in different health status.

\section{Bioavailability and Pharmacokinetics of Resveratrol}

After oral administration, RV is absorbed by passive diffusion or by forming complexes with membrane transporters followed by release into the bloodstream, where it can be found mainly as a glucuronide, sulfate, or free [20]. Phase II metabolism of RV or metabolites occurs in the liver, after an enterohepatic transport in the bile that may lead to some RV return to the small intestine [1].

Human clinical trials with RV showed its rapid metabolism [20,21]; it occurs in the liver and promotes the production of conjugated glucuronides and sulfate metabolites, which have biological activity [20]. The metabolites identified were measured by high-performance liquid chromatography analysis, followed by mass spectrometry.

Different clinical trials have found that the majority of plasma RV metabolites are RV-3-O-sulfate, RV-4'-O-glucuronide, and RV-3-O-glucuronide. RV-3-O-sulfate circulating levels showed the highest peak concentration compared to the other conjugated RV metabolites [22-25], except in one study where RV-3-O-glucuronide presented the highest peak concentration when the dose of RV was $2.5 \mathrm{~g}$ [25]. Pharmacokinetic studies revealed that RV concentration in plasma depends on the doses ingested [22,25-27].

In this section, we address research on the bioavailability and pharmacokinetics of RV in human clinical trials during the last 10 years. The subsections are organized according to the effects of different factors.

\subsection{Effect of Pharmaceutical Formulation and Particle Size}

Different strategies have been developed to improve RV efficacy [28], including pharmaceutical manipulation. A novel soluble formulation of trans-RV (caplets) was administered to 15 healthy subjects; the same amount of trans-RV (single dose of $40 \mathrm{mg}$ ) was also administered in dry powder (capsules). There were significant differences in bioavailability between the formulations, being the Cmax (maximum concentration) in plasma 8.8-fold higher for the soluble formulation [29].

$\mathrm{RV}$ can be absorbed, metabolized, and excreted in urine, in which up to 21 metabolites of RV have been identified [30]. The intake of $4.7 \mathrm{mg}$ of $\mathrm{RV}$ in grape extract tablets (as a nutraceutical) resulted in 
a delay of the urinary excretion of RV metabolites up to 4-fold higher compared with the intake of $6.3 \mathrm{mg}$ of RV in red wine [31]. This indicates a delayed absorption of RV when it is ingested in grape extract tablets. As a consequence, RV stays longer in the gut and could be metabolized by the gut microbiota. Therefore, RV supplementation can be a good source of this polyphenol.

Furthermore, reducing the size of the chemical particles can increase their absorption and kinetics [32]. The daily intake of $5 \mathrm{~g}$ microparticulate RV with a particle size of less than $5 \mathrm{~mm}$ (SRT501) for 14 days produced a higher peak plasma concentration than the equivalent dose of non-micronized RV [33], therefore a small particle size improves RV bioavailability.

\subsection{Matrix Effect}

The food matrix is important for RV bioavailability and pharmakocinetics. The bioavailability of RV was assessed when it was consumed together with food, quercetin, or ethanol in a study where $2000 \mathrm{mg}$ of trans-RV were administered twice daily for seven days to eight healthy subjects. In this clinical trial, the combined intake with other phenols such as quercetin and alcohol did not influence trans-RV pharmacokinetics. However, when RV was ingested within a high-fat breakfast compared with a standard breakfast, the area under the plasma concentration-time curve and the maximum plasma concentration were lower ( $45 \%$ and $46 \%$ decrease, respectively) [34]. In a two-way crossover study, 24 healthy subjects were administered $400 \mathrm{mg}$ of trans-RV with a high-fat content meal or in fasting conditions [35], and it was concluded that the presence of high-fat food delayed the rate of absorption of trans-RV but not the extent of absorption.

The solubility of trans-RV in water containing dextrose, fructose, ribose, sucrose, or xylitol was analyzed and compared. The best result was obtained with the ribose solution. A mixture of ribose and $146 \pm 5.5 \mathrm{mg}$ trans-RV was administered to two healthy human participants, leading to a higher and quicker RV release than that obtained with traditional free RV capsules [36]. A similar result was demonstrated when $250 \mathrm{mg}$ trans-RV doses were administered with $20 \mathrm{mg}$ of piperine to 23 healthy adults [23]. In this context, it is possible that the affinity for or the solubility of trans-RV in the presence of different substances such as soluble formulations, ribose, and piperine improves RV bioavailability when compared to the classic formulations (capsules).

Furthermore, a study with 36 healthy males ingesting capsules containing $800 \mathrm{mg}$ polyphenols with protein-rich dairy, soy, fruit-flavored drinks, or water, showed that the intake of polyphenols incorporated in protein-rich drinks did not change significantly the bioavailability of polyphenols or their metabolites [37].

A similar result was obtained when 59 high-risk adult subjects at high cardiovascular risk drank $272 \mathrm{~mL}$ of red wine (RW, $30 \mathrm{~g}$ ethanol/day) or dealcoholized red wine (DRW) every day for four weeks. The RV effect was independent of the alcohol in the red wine [38].

\subsection{Effects of Other Factors}

Repeated oral supplementation of trans-RV may influence pharmacokinetic variables. In this context, 13 doses of 25,50,100, or $150 \mathrm{mg}$ trans-RV were administered six times/day to four groups of eight healthy adults. Differences were observed between the peak trans-RV plasma concentrations after ingestion of the 1st and 13th dose, demonstrating the highest peak concentration for the latter. Moreover, trans-RV pharmacokinetic values were higher at 8 am and 12 pm [39], meaning that circadian variation and repeated doses affected the bioavailability.

It is important to remember that a wide range of factors such as gut microbiota composition, hormones, gender, and other interindividual differences can modify the structure of RV [40,41]. The gut microbiota plays an important role in the structure of RV, which can affect human health. In feces of healthy humans, Slackia Equolifaciens sp. and Adlercreutzia Equolifaciens sp. have been identified as dihydroresveratrol producers [40]. 


\subsection{Is It Safe to Consume Resveratrol?}

Clinical trials have shown that RV and trans-RV supplementation is safe and well tolerated at different doses [25,29,33,39,42-45]. However, some participants reported one or more adverse events, such as gastrointestinal symptoms including nausea, flatulence, bowel motions, abdominal discomfort, loose stools, and diarrhea, after ingesting a dose of 2.5 to $5 \mathrm{~g}$ of RV [22,25,34,42,43].

On the other hand, trans-RV half-life was one to three hours following single doses and two to five hours following repeated dosing [39]. It is noteworthy that the most important phase of RV excretion occurs in the first four hours after ingestion. Moreover, there exists a relationship between RV levels in plasma and in stools, indicating an enterohepatic recirculation [43].

For the above-mentioned reasons, the bioavailability and pharmacokinetics of RV depend on the doses ingested, the ingestion of food matrix, the particle size, and the role of the gut microbiota in the metabolism of RV. Last, RV intake is safe at a dose of up to $5 \mathrm{~g}$; however, adverse reactions have been observed at higher doses, which should be considered in future studies.

Figure 1 recapitulates the bioavailability and pharmacokinetics of RV. The image schematizes the results of different studies in which RV was identified in urine and blood. Additionally, Table 1 presents the details of the bioavailability and pharmacokinetics of RV in each study considered; it is organized according to health status and year of publication.

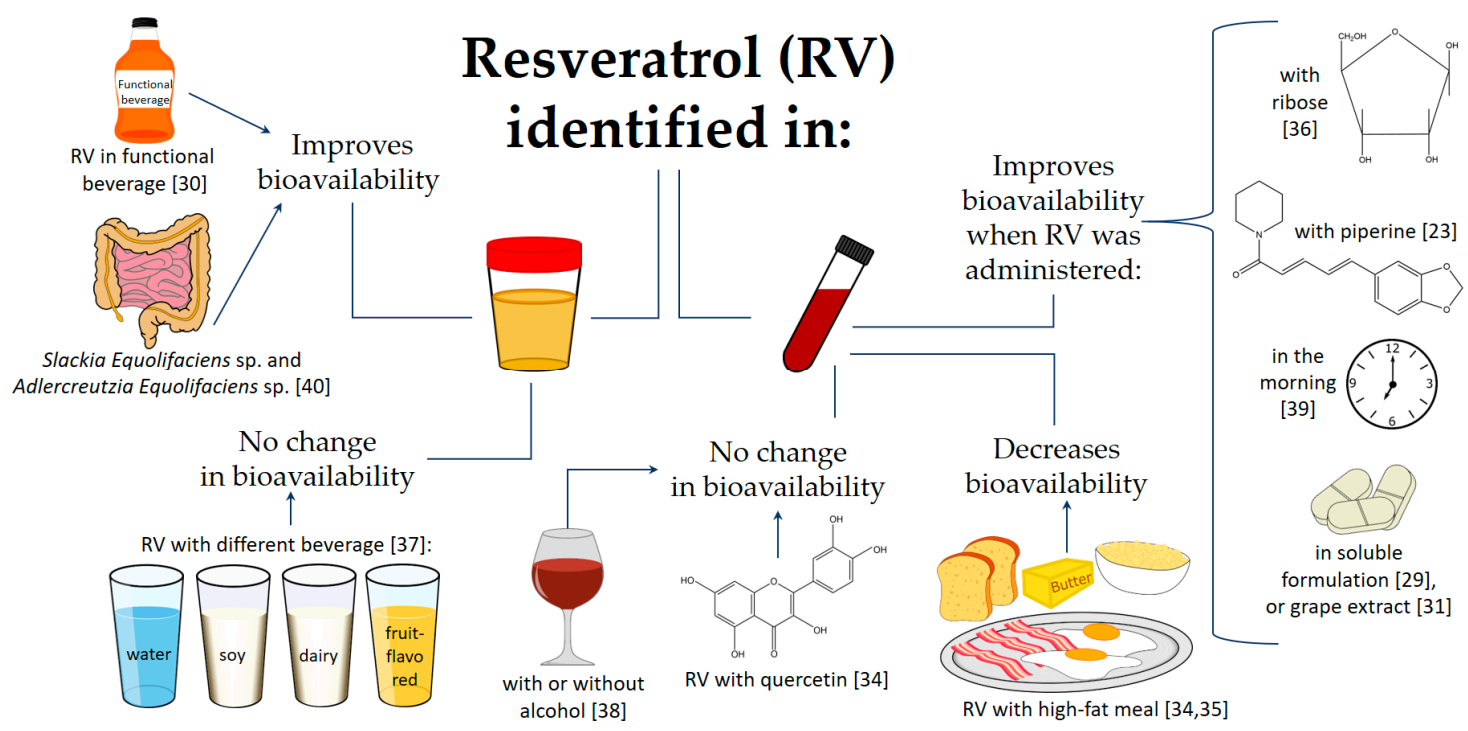

Figure 1. Bioavailability and pharmacokinetics. The image summarizes the results of different studies that identified resveratrol (RV) in urine and blood. 
Table 1. Studies of resveratrol bioavailability and pharmacokinetics in the last 10 years *.

\begin{tabular}{|c|c|c|c|c|c|c|c|}
\hline $\begin{array}{c}\text { Metabolite } \\
\text { (form of RV) }\end{array}$ & Sample & Type of Study & (n) & Dose & $\begin{array}{l}\text { Participants' } \\
\text { Health Status }\end{array}$ & Effect & Ref. \\
\hline $\begin{array}{l}\text { RV and six metabolites: } \\
\text { two monosulfates, one } \\
\text { disulfate, two } \\
\text { monoglucuronides, } \\
\text { and one } \\
\text { glucuronide-sulfate }\end{array}$ & Urine and feces & Clinical trial & 40 & $\begin{array}{l}\text { After a five-day washout, } 10 \text { subjects } \\
\text { received a } 0.5 \mathrm{~g} \text { dose, which was } \\
\text { escalated sequentially to } 1,2.5 \text {, and } 5 \mathrm{~g}\end{array}$ & Healthy & $\begin{array}{l}\text { An intake of up to one dose of } 5 \mathrm{~g} \\
\text { of RV was safe, with minor } \\
\text { adverse events in some cases; } \\
77 \% \text { of urinary excretion of RV } \\
\text { and its metabolites occurred } \\
\text { within four hours after the lowest } \\
\text { dose. RV underwent } \\
\text { enterohepatic recirculation. }\end{array}$ & [43] \\
\hline$t \mathrm{RV}$ & Plasma & $\begin{array}{l}\text { Randomized, } \\
\text { crossover, } \\
\text { open-label, and } \\
\text { single-dose }\end{array}$ & 24 & $\begin{array}{l}\text { Two treatments with a single dose of } 400 \\
\mathrm{mg} t \mathrm{RV} \text { after a high-fat meal or eight } \\
\text { hours without breakfast, separated by a } \\
\text { washout of seven days or more. }\end{array}$ & Healthy & $\begin{array}{l}\text { The rate of absorption of } t R V \text { was } \\
\text { reduced by the presence of a meal }\end{array}$ & [35] \\
\hline$t R V$ & Plasma & $\begin{array}{l}\text { Phase I, } \\
\text { randomized, } \\
\text { double-blind, } \\
\text { placebo-controlled, } \\
\text { and single-center }\end{array}$ & 40 & $\begin{array}{l}25,50,100 \text {, or } 150 \mathrm{mg} \text {, administered at } \\
\text { four hours intervals (six times/day) for } \\
48 \mathrm{~h} \text { (13 doses in total) }\end{array}$ & Healthy & $\begin{array}{l}\text { High daily doses of } t \mathrm{RV} \text { were } \\
\text { well tolerated but produced low } \\
\text { plasma } t \mathrm{RV} \text { levels; } t \mathrm{RV} \\
\text { bioavailability was higher when } \\
\text { it was administered in the } \\
\text { morning. }\end{array}$ & [39] \\
\hline$t \mathrm{RV}$ & Plasma & $\begin{array}{l}\text { Open-label and } \\
\text { single-arm }\end{array}$ & 8 & $\begin{array}{l}t R V 2000 \mathrm{mg} \text { twice daily for seven days } \\
\text { and } t \mathrm{RV} 2000 \mathrm{mg} \text { with quercetin } 500 \mathrm{mg} \\
\text { twice daily for seven days, with a } \\
\text { two-week washout period }\end{array}$ & Healthy & $\begin{array}{l}t \mathrm{RV} 2000 \mathrm{~g} \text { twice daily had } \\
\text { adequate exposure and was well } \\
\text { tolerated by subjects. Moreover, } \\
\text { combined intake with quercetin } \\
\text { did not influence its exposure }\end{array}$ & [34] \\
\hline $\begin{array}{l}\text { RV glucuronide and } \\
\text { sulfate conjugates, RV } \\
\text { glucoside, piceid } \\
\text { glucuronides, sulfates, } \\
\text { DHR, glucuronide, and } \\
\text { sulfate conjugates }\end{array}$ & Plasma and urine & $\begin{array}{l}\text { Randomized and } \\
\text { crossover }\end{array}$ & 10 & $\begin{array}{l}\text { After a three-day washout period, three } \\
\text { people were chosen for the pilot study in } \\
\text { which they consumed } 15 \text { grape extract } \\
\text { tablets (total RV } 4.72 \pm 0.07 \mathrm{mg} \text { ) with } 400 \\
\mathrm{~mL} \text { of water within } 10 \mathrm{~min} \text {. In parallel, } \\
\text { seven people were selected randomly to } \\
\text { drink } 375 \mathrm{~mL} \text { of red wine (total RV } 6.30 \\
\pm 0.09 \mathrm{mg} \text { ) with } 400 \mathrm{~mL} \text { of water } \\
\text { consumed within } 10 \mathrm{~min} \text {. }\end{array}$ & Healthy & $\begin{array}{l}\text { Statistically significant } \\
\text { differences between grape extract } \\
\text { tablets and red wine treatments } \\
\text { were obtained for some } \\
\text { metabolites, mainly due to the } \\
\text { different composition of RV and } \\
\text { piceid from both sources. The } \\
\text { grape extract tablets delayed RV } \\
\text { absorption compared to the red } \\
\text { wine treatment. }\end{array}$ & [31] \\
\hline $\begin{array}{l}\text { Free RV and conjugated } \\
\text { RV (monosulfate, } \\
\text { disulfate, and } \\
\text { glucoronide) }\end{array}$ & Plasma & Clinical trial & 15 & $\begin{array}{l}\text { Single dose }(40 \mathrm{mg}) \text { of } t R V \text { in soluble } \\
\text { formulation or dry powder }\end{array}$ & Healthy & $\begin{array}{l}\text { Bioavailability was higher with } \\
\text { soluble formulation compared to } \\
\text { dry powder. }\end{array}$ & [29] \\
\hline
\end{tabular}


Table 1. Cont.

\begin{tabular}{|c|c|c|c|c|c|c|c|}
\hline $\begin{array}{c}\text { Metabolite } \\
\text { (form of RV) }\end{array}$ & Sample & Type of Study & (n) & Dose & $\begin{array}{l}\text { Participants' } \\
\text { Health Status }\end{array}$ & Effect & Ref. \\
\hline $\begin{array}{c}\text { tRV, DHR, } \\
3,4^{\prime} \text {-dihydroxy-trans-stilbene, } \\
\text { and } \\
3,4^{\prime} \text {-dihydroxybibenzyl } \\
\text { (lunularin). }\end{array}$ & $\begin{array}{l}24 \mathrm{~h} \text { urine } \\
\text { and feces }\end{array}$ & $\begin{array}{l}\text { Controlled } \\
\text { intervention }\end{array}$ & 12 & 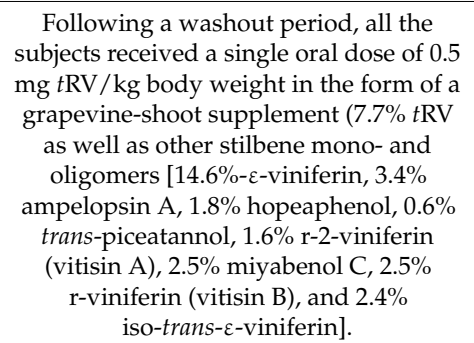 & Healthy & $\begin{array}{l}\text { The human gut microbiota } \\
\text { produced pronounced } \\
\text { interindividual differences in } t \mathrm{RV} \text {. } \\
\text { Slackia Equolifaciens sp. and } \\
\text { Adlercreutzia Equolifaciens sp. } \\
\text { were identified as DHR } \\
\text { producers, but the bacteria that } \\
\text { produce dehydroxylated } \\
\text { metabolites were not determined. }\end{array}$ & [40] \\
\hline$t \mathrm{RV}$ & Plasma & Pilot study & 2 & $\begin{array}{l}146+/-5.5 \mathrm{mg} t \mathrm{RV} \text { per } 2000 \mathrm{mg} \text { of } \\
\text { lozenge mass, containing about } 46 \% \\
\text { ribose, } 46 \% \text { (fructose/sucrose mixture), } \\
\text { and } 8 \% t \mathrm{RV}\end{array}$ & Healthy & $\begin{array}{l}\text { A mixture of ribose and RV oral } \\
\text { transmucosal administration } \\
\text { achieved a much higher and } \\
\text { quicker RV release compared to } \\
\text { the reported traditional free RV } \\
\text { capsules. }\end{array}$ & [36] \\
\hline Free and conjugated RV & Plasma & $\begin{array}{l}\text { Randomized and } \\
\text { three-way } \\
\text { crossover }\end{array}$ & 15 & $\begin{array}{l}\text { Oral doses equivalent to } 50 \mathrm{mg} \text { or } 150 \\
\mathrm{mg} \text { of } t \mathrm{RV} \text { or plant-derived RV }(150 \mathrm{mg}) \\
\text { on three occasions separated by } \\
\text { seven-dav washout periods. }\end{array}$ & Healthy & $\begin{array}{c}150 \mathrm{mg} \text { dose of } t \mathrm{RV} \text { showed } \\
\text { higher total and free levels than } \\
50 \mathrm{mg} \text { dose }\end{array}$ & [46] \\
\hline $\begin{array}{l}\text { tRV, RV, 3-O-sulphate, } \\
\text { RV 4'-O-glucuronide, and } \\
\text { RV 3-O-glucuronide }\end{array}$ & Plasma & $\begin{array}{l}\text { Randomized, } \\
\text { double-blind, and } \\
\text { placebo-controlled }\end{array}$ & 23 & $\begin{array}{c}250 \mathrm{mg} \text { of } t \mathrm{RV} \text { or } 250 \mathrm{mg} \text { of } t \mathrm{RV} \text { with } 20 \\
\mathrm{mg} \text { of piperine on separate days at least a } \\
\text { week apart. }\end{array}$ & Healthy & $\begin{array}{l}\text { Piperine co-supplementation } \\
\text { with } 250 \mathrm{mg} \text { of } t \mathrm{RV} \text { or } 250 \mathrm{mg} \text { of } \\
t \mathrm{RV} \text {; piperine enhanced the } \\
\text { absorption of the polyphenol } \\
\text { leading to an increase in cerebral } \\
\text { blood flow. }\end{array}$ & [23] \\
\hline $\begin{array}{c}\text { tR4G, cR4G, tR3G, cR3G, } \\
\text { tR4S, cR4S, } t \text { R3S, cR3S, } \\
\text { tR34dS, RV-SG, } \\
\text { tpiceid, cpiceid, } \\
\text { Pic-G, Pic-S1, Pic-S2, DHR, } \\
\text { DHR-G1, DHR-G2, } \\
\text { DHR-S1, DHR-S2, and } \\
\text { DHR-SG }\end{array}$ & $24 \mathrm{~h}$ urine & $\begin{array}{l}\text { Randomized, } \\
\text { double-blind, } \\
\text { placebo-controlled, } \\
\text { crossover, and } \\
\text { intervention study }\end{array}$ & 26 & $\begin{array}{l}\text { Consumed twice a day (with breakfast } \\
\text { and dinner) for } 15 \text { days (per each phase) } \\
187 \mathrm{~mL} \text { of: a control placebo and a } \\
\text { functional beverage ( } 4280 \mathrm{~g} / \mathrm{L} \text { of } \\
\text { hydroxycinnamic acids, } 16 \mathrm{mg} / \mathrm{L} \text { of } \\
\text { anthocyanins, } 96 \mathrm{mg} / \mathrm{L} \text { of flavanols, } 83 \\
\text { mg/L of hydroxybenzoic acids, } \\
\text { and } 5.7 \mathrm{mg} / \mathrm{L} \text { of stilbenes) }\end{array}$ & Healthy & $\begin{array}{l}\text { The whole profile of the } 21 \mathrm{RV} \\
\text { metabolites increased after acute } \\
\text { and chronic consumption of the } \\
\text { functional beverage with respect } \\
\text { to the control-placebo beverage } \\
\text { and to the baseline. }\end{array}$ & [30] \\
\hline
\end{tabular}


Table 1. Cont.

\begin{tabular}{|c|c|c|c|c|c|c|c|}
\hline $\begin{array}{c}\text { Metabolite } \\
\text { (form of RV) }\end{array}$ & Sample & Type of Study & (n) & Dose & $\begin{array}{c}\text { Participants' } \\
\text { Health Status }\end{array}$ & Effect & Ref \\
\hline $\begin{array}{l}\text { Phenolic acids including, } \\
\text { 3-hydroxyphenylacetic } \\
\text { acid, } \\
\text { 3-hydroxyhippuric acid, } \\
\text { 4-hydroxyhippuric acid, } \\
\text { and Hippuric Acid, }\end{array}$ & $24 \mathrm{~h}$ urine & $\begin{array}{l}\text { Randomized, } \\
\text { placebo-controlled, } \\
\text { and crossover }\end{array}$ & 35 & $\begin{array}{l}\text { Six placebo gelatin capsules consumed } \\
\text { with } 200 \mathrm{~mL} \text { of water (control) } \\
\text { Six capsules containing } 800 \mathrm{mg} \\
\text { polyphenols (141 mg anthocyanins, } \\
24 \mathrm{mg} \text { flavan-3-ols, } 16 \mathrm{mg} \text { procyanidins, } \\
10 \mathrm{mg} \text { phenolic acids, } 9 \mathrm{mg} \text { flavonols, } \\
\text { and } 1 \mathrm{mg} \text { stilbenes) derived from red } \\
\text { wine and grape extracts, or the same } \\
\text { dose of polyphenols incorporated into } \\
\text { one of the following: } 200 \mathrm{~mL} \text { of water } \\
\text { (positive control), } 200 \mathrm{~g} \text { of dairy drink, } \\
200 \mathrm{~g} \text { of soy drink, } 200 \mathrm{~g} \text { fruit-flavored } \\
\text { drink, or protein-free drink. }\end{array}$ & Healthy & $\begin{array}{l}\text { Bioavailability of polyphenols } \\
\text { and the excretion of their } \\
\text { phenolic metabolites were not } \\
\text { significantly affected when } \\
\text { polyphenols were consumed in } \\
\text { protein-rich soy or dairy drinks. }\end{array}$ & {$[37]$} \\
\hline Total RV & Plasma & $\begin{array}{l}\text { Randomized and } \\
\text { double-blind }\end{array}$ & 9 & $\begin{array}{l}5 \mathrm{~g} / \text { day of SRT501 for approximately } \\
14 \text { days }\end{array}$ & $\begin{array}{l}\text { IV colorectal } \\
\text { cancer and hepatic } \\
\text { metastasis subjects } \\
\text { scheduled to } \\
\text { undergo } \\
\text { hepatectomy. }\end{array}$ & $\begin{array}{l}\text { RV treatment was well tolerated } \\
\text { by the patients. The peak plasma } \\
\text { after ingestion of SRT501 was } \\
1.942 \mathrm{ng} / \mathrm{m} \text {, higher than that of } \\
\text { an equivalent dose of } \\
\text { non-micronized RV } \\
\text { supplementation. }\end{array}$ & [33] \\
\hline $\begin{array}{c}t R 4 G, c R 4 G, t R 3 G, c R 3 G, \\
t \text { R4S, cR4S, } t \text { R3S, cR3S, } \\
\text { tR34dS, RV-SG, } \\
\text { tpiceid, cpiceid, } \\
\text { Pic-G, Pic-S1, Pic-S2, DHR, } \\
\text { DHR-G1, DHR-G2, } \\
\text { DHR-S1, DHR-S2, and } \\
\text { DHR-SG }\end{array}$ & $24 \mathrm{~h}$ urine & $\begin{array}{l}\text { Randomized, } \\
\text { crossover, and } \\
\text { controlled clinical } \\
\text { trial }\end{array}$ & 59 & $\begin{array}{l}\text { 15-day run-in period in which they } \\
\text { consumed neither grape-derived } \\
\text { products nor alcoholic beverages. } \\
\text { Afterwards, they consumed every day } \\
\text { for four weeks: } 272 \mathrm{~mL} \text { of } \mathrm{RW} \text { (red wine) } \\
\text { with } 30 \mathrm{~g} \text { ethanol/day or } 272 \mathrm{~mL} \text { of DRW } \\
\text { (dealcoholized red wine), following the } \\
\text { same background diet. }\end{array}$ & $\begin{array}{c}\text { High } \\
\text { cardiovascular risk }\end{array}$ & $\begin{array}{l}\text { The whole profile of the } 21 \mathrm{RV} \\
\text { metabolites increased after RW } \\
\text { and DRW consumption, and no } \\
\text { differences between them } \\
\text { were presented }\end{array}$ & {$[38]$} \\
\hline
\end{tabular}

cpiceid: cis-3,4' 5-trihydroxystilbene-3- $\beta$-D-glucopyranoside, $c$ R3G: cis-RV-3-O-glucuronide, $c$ R3S: cis-RV-3-O-sulfate, $c$ R4G: cis-RV-4'-O-glucuronide, $c$ R4S: cis-RV-4'-O-sulfate, DHR Dihydroresveratrol, DHR-G1: DHR glucuronide 1, DHR-G2: DHR glucuronide 2, DHR-S1: DHR sulfate 1, DHR-S2: DHR sulfate 2, DHR-SG: DHR sulfoglucuronide, Pic-G: piceid-glucuronide, Pic-S1: Piceid sulfate 1, Pic-S2: Piceid sulfate 2, RV: resveratrol, RV-SG: RV sulfoglucuronide, SRT501: microparticular RV of particle size less than 5um, tpiceid: trans-3,4',5-trihydroxystilbene-3- $\beta$-D-glucopyranoside, $t$ RV: trans-RV, $t R 3 G$ : trans-RV-3-O-glucuronide, $t$ R3S: trans-RV-3-O-sulfate, $t R 4 G$ : trans-RV-4'-O-glucuronide, $t R 4 S$ : trans-RV-4'-O-sulfate, and $t \mathrm{R} 34 \mathrm{dS}$ : trans-RV-3,4'-O-disulfate, * Studies which identified resveratrol or some metabolite of resveratrol in plasma, urine, and/or feces. 


\section{Different Health Effects of Resveratrol}

This section addresses research on the effect of RV in human clinical trials in the last 10 years. The subsections are organized according to the different health status or diseases under research.

\subsection{Effects of Resveratrol on Neurological Diseases and Cognitive Performance}

$\mathrm{RV}$ is associated with a slowing down or prevention of cognitive deterioration [11]. Although few clinical trials have focused on the effect of RV on Alzheimer's disease (AD), two studies suggest that $\mathrm{RV}$ may change some AD biomarkers. Both studies are rated class II because more than two primary outcomes were designated. A dose of $500 \mathrm{mg}$ RV/day was administered to patients with mild to moderate $\mathrm{AD}$, with $500 \mathrm{mg}$ increments every 13 weeks up to 52 weeks, ending with $1000 \mathrm{mg}$ twice daily. In one of the studies, the brain volume decreased in the RV group; however, the mechanisms of this event were unclear, and cognitive deterioration was not indicated. Both the RV and placebo group showed a decline of A $\beta 40$ (beta amyloid) levels in the cerebrospinal fluid (CSF) or plasma at 52 weeks [24]. A subsequent study reported similar results for CSF A $\beta 40$ compared to baseline, whereas a greater reduction of CSF A $\beta 42$ occurred in the placebo group when compared to the group receiving the $R V$ treatment, indicating that $R V$ could attenuate the progressive decline of this biomarker of AD. In plasma, RV increased MMP10 (matrix metalloproteinase) and reduced IL-12P40 (interleukin) and IL-12P70. Compared to the placebo, the RV treatment reduced MMP9 in CSF [47]. From the evidence described above, RV may regulate neuro-inflammation in AD patients; however, more studies are needed to draw conclusions about RV efficacy in AD.

In 36 adult patients with type 2 diabetes (T2D), a single dose of $75 \mathrm{mg}$ of RV ingested at weekly intervals showed significant changes, enhancing neurovascular coupling capacity and improving cognitive performance [27].

On the other hand, single doses of 250 and $500 \mathrm{mg}$ trans-RV in two different days, in healthy subjects, improved cerebral blood flow variables, with increases of total hemoglobin $(\mathrm{Hb})$ and oxygenated $\mathrm{Hb}($ oxy- $\mathrm{Hb})$ and a reduction of deoxy- $\mathrm{Hb}$ concentration; nevertheless, it did not produce any change in cognitive performance variables [48]. In a consecutive study, a similar result was reported with 23 healthy adults who ingested two capsules with a dose of $250 \mathrm{mg}$ trans-RV and $20 \mathrm{mg}$ of piperine (a pepper-derived alkaloid) in three different days. A significant increase in total- $\mathrm{Hb}$ and oxy-Hb was observed, but without any improvement in cognitive functioning [23].

A possible explanation for the contrasting results could be that a different methodology to evaluate cognitive performance was used in these studies. When a more objective measure is used, such as near-IR spectroscopy, the results are not as clear as when the results are based on cognitive test batteries. Likewise, it could be interesting to know the capsule composition, because it could contribute to the observed different effect.

The effects of RV have been observed in other neurological diseases such as Friedreich ataxia. The effect of $5 \mathrm{~g}$ of RV ingested daily for 12 weeks was studied in patients diagnosed with the aforementioned disease, showing an improvement in neurologic function, audiologic and speech measures, and oxidative stress marker plasma F2-isoprostane [25].

\subsection{Effects of Resveratrol on Diabetes Mellitus}

RV enhances the endothelial function, increases liver fatty acid oxidation, and decreases oxidative stress [49], leading to an improvement in insulin sensitivity [50]. A study in which 10 overweight individuals with impaired glucose tolerance were administered 1, 1.5, or $2 \mathrm{~g}$ of RV per day for four weeks, showed that insulin sensitivity and postprandial glucose levels were improved by RV intake [45]. In another clinical study, 17 volunteers with T2D were treated with $150 \mathrm{mg}$ /day of RV for 30 days, after which, intrahepatic lipid content and systolic blood pressure decreased. Similarly, when overweight and obese men were administered RV for two weeks, $1 \mathrm{~g}$ in the first week and $2 \mathrm{~g}$ in the second, a reduction in intestinal and hepatic lipoprotein particle production was observed. 
RV diminished the production rate of ApoB- 48 and both the production and fractional catabolic rates of ApoB-100, compared to a placebo [51].

Nevertheless, RV did not enhance hepatic and peripheral insulin sensitivity, which could be explained by a negative interaction with metformin in the patients receiving this kind of treatment [52]. Similar results were reported in 20 overweight or obese men with non-alcoholic fatty liver disease when given a daily dose of $3 \mathrm{~g}$ RV for eight weeks. No reduction in insulin resistance, steatosis, abdominal fat distribution, plasma lipids, or antioxidant activity was observed. However, an increase of alanine and aspartate aminotransferases with RV supplementation was observed, due to RV increased hepatic stress [42].

Some studies have analyzed the effect of RV on obesity. A daily dose of $150 \mathrm{mg} /$ day of RV for four weeks was given to 10 slightly obese adults. RV supplementation suppressed postprandial glucagon, which may be important for the treatment of T2D because an excess of this hormone contributes to patient hyperglycemia [53]. Contrasting results can be explained by the effect of the pharmacokinetics of different medications on RV or by liver's health, because both RV and other medications could be metabolized in the liver; nevertheless, the main reason could be the dose taken.

\subsection{Effect of Resveratrol on Cancer}

The insulin-like growth factor (IGF) signaling pathway, including IGFs, IGF-binding proteins (IGFBP), and IGF receptors, is related to the anticarcinogenic effects linked to dietary restriction. In parallel, RV can act as a chemopreventive agent and a calorie-restriction mimetic in humans $[9,54]$. Related to these effects, RV decreased IGF-I and IGFBP-3 in 40 healthy volunteers who consumed RV at $0.5,1.0,2.5$, or $5.0 \mathrm{~g}$ daily for 29 days, leading to a reduction of cancer risk. The highest reduction was observed with a $2.5 \mathrm{~g}$ dose. Therefore, it was concluded that the IGF system could act as a biomarker of RV chemopreventive action in humans [22].

\subsection{Effect of Resveratrol on Cardiovascular Diseases}

Flow-mediated dilatation (FMD) of the brachial artery is a biomarker of endothelial function and cardiovascular health, with notable importance as an indicator of structural and functional endothelium changes [55,56]. A $270 \mathrm{mg}$ dose of RV administered weekly for four weeks to 14 overweight or obese men or five post-menopausal women with untreated borderline hypertension significantly increased FMD [26]. In another study, RV in red wine was associated with improved levels of glucose and triglycerides, as well as a lower heart rate, whereas no effect was observed for total cholesterol, HDL, LDL, and high blood pressure [57]. However, in overweight individuals, the intake of $150 \mathrm{mg}$ per day of RV for four weeks did not influence metabolic risk markers such as endothelial function or inflammation, which are related to cardiovascular health risk [58,59]. A possible reason for the contrasting results could be related to the ingested dose of $R V$, because a positive effect of $R V$ in higher doses on other diseases has been observed. However, it is important to note that the first mentioned work [26] had a significantly lower number of participants than the last one [58,59].

\subsection{Effect of Resveratrol on Obesity}

In a crossover study with 11 subjects, RV mimicked the effect of calorie restriction, reducing the metabolic rate, activating AMPK in muscle, and increasing the levels of SIRT1 and peroxisome proliferator-activated receptor gamma coactivator 1 alpha protein. RV also increased the activity of citrate synthase and decreased the lipid content inside the liver, the levels of circulating glucose, triglycerides, alanine aminotransferase, and other inflammation markers. The homeostatic model assessment index was also improved after the intervention [60].

To analyze the longer-term effect of some polyphenols on the metabolic profile, RV and epigallocatechin-3-gallate supplements ( 80 and $282 \mathrm{mg}$ /day, respectively) were administered during a period of 12 weeks to 38 overweight or obese subjects. An increase in mitochondrial capacity and fat oxidation stimulation was observed, together with a better skeletal muscle oxidative capacity and a 
preservation of fasting and postprandial fat oxidation. Consequently, triacylglycerol concentration remained unchanged after the RV treatment, unlike in the placebo group, but no improvement of insulin resistance was found in peripheral, hepatic, or adipose tissue [61].

\subsection{Effect of Resveratrol on Other Health Conditions Associated with Oxidative Stress and Inflammation}

The antioxidant effects of RV have been widely studied. In a study with 10 healthy individuals, a single dose of $5 \mathrm{~g}$ of RV was given, and a significant increase of tumor necrosis factor-alpha (TNF- $\alpha$ ) in plasma was found after $24 \mathrm{~h}$. This enhanced production, as well as the inhibition of IL-10, was confirmed by analysis of peripheral blood mononuclear cells (PBMC), which were activated with different toll-like receptor agonists [62].

In a different trial with nine healthy men and women, who ingested $1 \mathrm{~g} /$ day $R V$ capsules for 28 days, $R V$ effect on immune cells was assessed. The results showed that RV induced an increase in circulating $T$ cells and was consequently able to reduce the plasma levels of proinflammatory cytokines TNF- $\alpha$ and monocyte chemoattractant protein 1 ; moreover, RV significantly increased the plasma antioxidant capacity with a resulting decrease of oxidative stress markers involved in DNA damage [63].

A study consisting in the administration of $75 \mathrm{mg} /$ day of RV per 12 weeks to non-obese, postmenopausal women with normal glucose tolerance, did not observe any change in inflammatory markers, body composition, resting metabolic rate, plasma lipids, liver, skeletal muscle, and adipose tissue volumes, or insulin sensitivity [44].

Lastly, in a study with patients undergoing peritoneal dialysis, the daily consumption of $450 \mathrm{mg}$ of RV over 12 weeks improved urinary ultrafiltration and decreased vascular endothelial growth factor, fetal liver kinase-1, and angiopoietin-2 (angiogenesis markers) when the highest dose was ingested [64].

A possible reason for the contrasting results could be that low doses [44] or a single but higher dose [62] do not have positive health effects and, furthermore, they may cause an acute metabolic stress. On the other hand, a moderate $(>450 \mathrm{mg})$ but continuing intake $[63,64]$ has demonstrated an improved effect of RV. These results suggest that a repeated and moderate administration of RV is better than a single, higher dose administration. Figure 2 schematizes the results of different studies from the last 10 years in which RV had a healthy effect. Additionally, Table 2 presents the details of the effect of RV in each study analyzed. The table is organized according to the participants' health status.

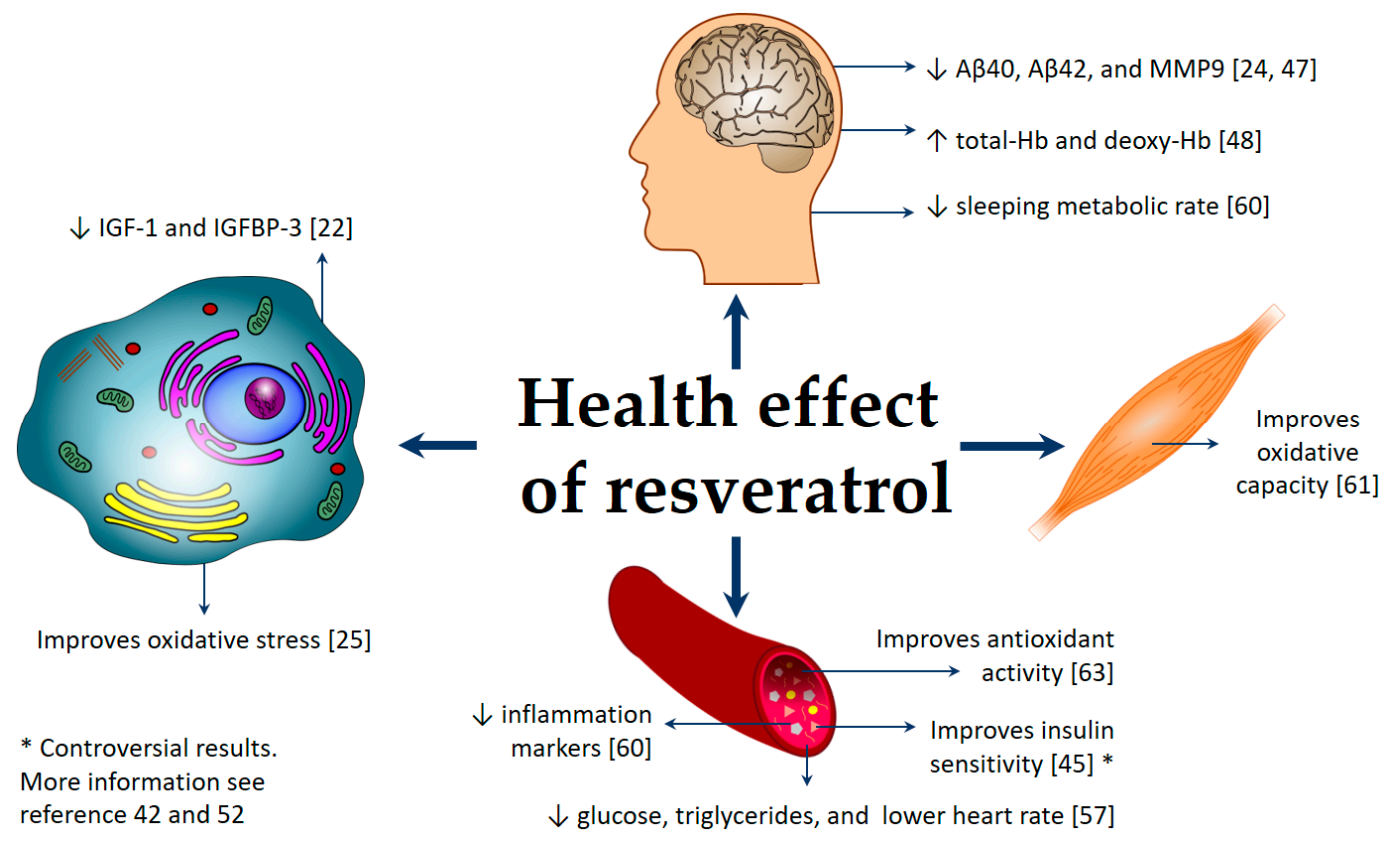

Figure 2. Health effects of resveratrol. A summary of the results of different studies reporting a positive effect of RV on health. 
Table 2. Effects of resveratrol on individuals with different health status reported in the last 10 years *.

\begin{tabular}{|c|c|c|c|c|c|c|c|}
\hline $\begin{array}{c}\text { Metabolite } \\
\text { (form of RV) }\end{array}$ & Sample & Type of Study & (n) & Dose & $\begin{array}{c}\text { Participants' Health } \\
\text { Status }\end{array}$ & Effect & Ref. \\
\hline $\begin{array}{l}\quad \mathrm{RV} \\
\text { 3-O-glucuronidated-RV, } \\
\text { 4-O-glucuronidated-RV, } \\
\text { and 3-sulfated-RV }\end{array}$ & Plasma & $\begin{array}{l}\text { Phase II, randomized, } \\
\text { double-blind, } \\
\text { placebo-controlled, } \\
\text { and multi-center }\end{array}$ & 119 & $\begin{array}{c}500 \mathrm{mg} / \text { day RV with } 500 \\
\mathrm{mg} \text { increments every } 13 \\
\text { weeks up to } 52 \text { weeks, } \\
\text { ending with } 1000 \mathrm{mg} \\
\text { twice daily }\end{array}$ & Alzheimer & $\begin{array}{c}\text { RV was safe and well tolerated, decreased } \\
\text { A } \beta 40 \text { and MMP9 in CSF, modulated } \\
\text { neuroinflammation, and induced adaptive } \\
\text { immunity. }\end{array}$ & {$[24,47]$} \\
\hline $\begin{array}{l}\text { RV, RV-3-glucuronide, } \\
\text { RV-4'-glucuronide, } \\
\text { and } \\
\text { RV-3-sulfate }\end{array}$ & Plasma & $\begin{array}{l}\text { Non-randomized, and } \\
\text { open-label }\end{array}$ & 24 & $\begin{array}{l}\text { Low-dose RV ( } 1 \mathrm{~g} \text { daily) } \\
\text { or high-dose RV (5 g daily) } \\
\text { over a 12-week period }\end{array}$ & Friedreich ataxia & $\begin{array}{l}\text { PBMC frataxin protein levels were not } \\
\text { affected. High-dose RV treatment showed a } \\
\text { beneficial effect on both oxidative stress and } \\
\text { some clinical outcome measures. }\end{array}$ & [25] \\
\hline $\begin{array}{l}\mathrm{RV} \text { and dehydro RV } \\
\text { (aglycones and } \\
\text { glucuronide } \\
\text { conjugates) }\end{array}$ & Plasma & $\begin{array}{l}\text { Randomized, } \\
\text { double-blind, and } \\
\text { crossover }\end{array}$ & 17 & $\begin{array}{l}150 \mathrm{mg} / \text { day of resVida } \\
\text { (RV) for } 30 \text { days }\end{array}$ & $\mathrm{T} 2 \mathrm{D}$ & $\begin{array}{l}\text { Intrahepatic lipid content correlated } \\
\text { negatively with the plasma RV content. RV } \\
\text { plasma levels might be affected by } \\
\text { metformin treatment; RV did not improve } \\
\text { insulin sensitivity. }\end{array}$ & [52] \\
\hline $\begin{array}{l}\text { TRM: } t \text { R3G, } c \text { R4G, } \\
c \text { R3G, } t \text { R4S, } t \text { R3S, } \\
c \text { R4S, and cR3S }\end{array}$ & Urine & $\begin{array}{c}\text { Randomized, } \\
\text { parallel-group, } \\
\text { multi-center, and } \\
\text { controlled clinical trial }\end{array}$ & 1000 & $\begin{array}{l}\text { Exploratory study of the } \\
\text { baseline data of } \\
\text { PREDIMED study }\end{array}$ & $\begin{array}{l}\text { T2D or at less three major } \\
\text { cardiovascular risk factors }\end{array}$ & $\begin{array}{l}\text { Total urinary RV metabolites were directly } \\
\text { associated with lower concentrations of } \\
\text { fasting blood glucose and triglycerides, and } \\
\text { also with lower heart rate. No significant } \\
\text { associations were observed between TRM } \\
\text { and total cholesterol, HDL, and LDL } \\
\text { concentrations, or blood pressure. Therefore, } \\
\text { RV may help to decrease cardiovascular risk. }\end{array}$ & [57] \\
\hline Total RV & Plasma & Randomized & 10 & $\begin{array}{c}1,1.5, \text { and } 2 \mathrm{~g} / \text { day } R V \\
\text { taken in divided doses for } \\
\text { four weeks }\end{array}$ & $\begin{array}{l}\text { Overweight or obese and } \\
\text { insulin resistant. }\end{array}$ & $\begin{array}{l}\text { Fasting glucose was unchanged, but } \\
\text { postprandial glucose and three-hour glucose } \\
\text { area under the curve decreased significantly. } \\
\text { Insulin sensitivity (using the Matsuda index) } \\
\text { improved. Fasting lipid profile, CRP, and } \\
\text { adiponectin were unchanged. }\end{array}$ & [45] \\
\hline Total RV & Plasma & $\begin{array}{c}\text { Randomized, } \\
\text { double-blind, and } \\
\text { placebo-controlled }\end{array}$ & 20 & $\begin{array}{c}3000 \mathrm{mg} / \text { day RV for eight } \\
\text { weeks }\end{array}$ & $\begin{array}{l}\text { Overweight or obese with } \\
\text { non-alcoholic fatty liver } \\
\text { disease }\end{array}$ & $\begin{array}{l}\text { RV did not improve insulin sensitivity, } \\
\text { plasma lipids, antioxidant activity, and } \\
\text { IGF-1, but it increased ALT and AST, liver } \\
\text { enzymes that indicate hepatic stress. }\end{array}$ & [42] \\
\hline Total RV & Plasma & $\begin{array}{l}\text { Randomized, } \\
\text { double-blind, } \\
\text { placebo-controlled, } \\
\text { and crossover }\end{array}$ & 19 & $\begin{array}{l}\text { A single dose of RV (30, } \\
90 \text {, and } 270 \mathrm{mg}) \\
\text { administered at one-week } \\
\text { intervals over four weeks }\end{array}$ & $\begin{array}{l}\text { Overweight and obese } \\
\text { individuals or } \\
\text { postmenopausal women } \\
\text { with untreated borderline } \\
\text { hypertension }\end{array}$ & $\begin{array}{l}\text { Significant linear relationship between RV } \\
\text { dose intake and plasma RV concentration. } \\
\text { Higher plasma RV concentration was } \\
\text { associated with acute flow-mediated } \\
\text { dilatation response. }\end{array}$ & [26] \\
\hline
\end{tabular}


Table 2. Cont

\begin{tabular}{|c|c|c|c|c|c|c|c|}
\hline $\begin{array}{c}\text { Metabolite } \\
\text { (form of RV) }\end{array}$ & Sample & Type of Study & (n) & Dose & $\begin{array}{l}\text { Participants' Health } \\
\text { Status }\end{array}$ & Effect & Ref. \\
\hline $\begin{array}{l}\text { Total conjugated, } \\
\text { unconjugated RV, and } \\
\text { DHR }\end{array}$ & Plasma & $\begin{array}{l}\text { Randomized, } \\
\text { double-blind, and } \\
\text { crossover }\end{array}$ & 11 & $\begin{array}{c}150 \mathrm{mg} / \text { day RV for } 30 \\
\text { days }\end{array}$ & Obese & $\begin{array}{l}\text { RV supplementation modestly mimicked the } \\
\text { beneficial effects of calorie restriction. It } \\
\text { reduced sleeping metabolic rate, affected the } \\
\text { AMPK-SIRT1-PGC1 } \alpha \text { axis, decreased } \\
\text { hepatic lipid accumulation. and reduced } \\
\text { inflammation markers. }\end{array}$ & {$[60]$} \\
\hline $\begin{array}{l}\text { Epigallocatechin-3-gallate, } \\
\text { RV, and DHR }\end{array}$ & Plasma & $\begin{array}{l}\text { Randomized, } \\
\text { double-blind, } \\
\text { placebo-controlled, } \\
\text { and parallel } \\
\text { intervention }\end{array}$ & 38 & $\begin{array}{l}\text { Epigallocatechin-3-gallate } \\
+\mathrm{RV} 282 \text { and } 80 \mathrm{mg} / \text { day, } \\
\text { respectively for } 12 \text { weeks }\end{array}$ & Overweight and obese & $\begin{array}{l}\text { The supplementation improved skeletal } \\
\text { muscle oxidative capacity, preserved fasting } \\
\text { and postprandial fat oxidation, and } \\
\text { prevented an increase in triacylglycerol } \\
\text { concentrations. }\end{array}$ & [61] \\
\hline $\begin{array}{l}\text { Total RV and DHR } \\
\text { (both free and } \\
\text { conjugated) }\end{array}$ & Plasma & $\begin{array}{l}\text { Randomized, } \\
\text { placebo-controlled, } \\
\text { and crossover }\end{array}$ & 45 & $\begin{array}{l}150 \mathrm{mg} / \text { day RV capsule } \\
\text { for four weeks, with a } \\
\text { four-week wash-out } \\
\text { period }\end{array}$ & $\begin{array}{l}\text { Overweight and } \\
\text { slightly obese }\end{array}$ & $\begin{array}{l}\mathrm{RV} \text { did not have an effect on cardiovascular } \\
\text { risk metabolic markers, endothelial function, } \\
\text { or inflammation. }\end{array}$ & {$[58,59]$} \\
\hline $\begin{array}{l}\text { Total RV and DHR } \\
\text { (free and conjugated } \\
\text { forms) }\end{array}$ & Plasma & $\begin{array}{l}\text { Randomized, } \\
\text { double-blind, and } \\
\text { placebo-controlled }\end{array}$ & 45 & $\begin{array}{l}75 \mathrm{mg} / \text { day }(99 \% \text { pure } \\
t \mathrm{RV}), \text { for } 12 \text { weeks. }\end{array}$ & $\begin{array}{l}\text { Lean and overweight, } \\
\text { postmenopausal }\end{array}$ & $\begin{array}{l}\text { RV supplementation did not change plasma } \\
\text { substrates and hormones (glucose, plasma } \\
\text { lipids, and insulin), adiponectin, leptin, CRP, } \\
\text { and IL-6. }\end{array}$ & [44] \\
\hline $\begin{array}{c}\text { Total RV, RV } \\
\text { glucuronide, and RV } \\
\text { sulfate }\end{array}$ & Plasma & $\begin{array}{l}\text { Randomized, } \\
\text { double-blind, } \\
\text { placebo-controlled, } \\
\text { and crossover }\end{array}$ & 22 & $\begin{array}{l}250 \text { and } 500 \mathrm{mg} t \mathrm{RV} \text { on } \\
\text { separate days. On three } \\
\text { visits, the participants } \\
\text { received two single-dose } \\
\text { capsules. The capsules } \\
\text { were combined to give the } \\
\text { following treatments: } 1 \text { ) } \\
\text { inert placebo, 2) } 250 \mathrm{mg} \\
t \mathrm{RV} \text {, and 3) } 500 \mathrm{mg} t \mathrm{RV} \text {. }\end{array}$ & Healthy & $\begin{array}{l}\mathrm{RV} \text { intake increased total- } \mathrm{Hb} \text { and deoxy-Hb } \\
\text { concentration, variables related to cerebral } \\
\text { blood flow. }\end{array}$ & [48] \\
\hline $\begin{array}{c}t \mathrm{R} 4 \mathrm{G}, t \mathrm{RDS}, t \mathrm{R} 3 \mathrm{G}, \\
t \mathrm{R} 4 \mathrm{~S}, \text { and } t \mathrm{R} 3 \mathrm{~S}\end{array}$ & Plasma & $\begin{array}{l}\text { Pilot study, } \\
\text { randomized, } \\
\text { open-label, } \\
\text { single-dose, and } \\
\text { parallel-group }\end{array}$ & 10 & Single $5 \mathrm{~g}$ dose & Healthy & $\begin{array}{c}\text { RV increased TNF- } \alpha \text { level } 24 \mathrm{~h} \text { after } \\
\text { supplementation, by an average of } 3.5 \\
\mathrm{pg} / \mathrm{mL} \text {, compared with placebo. High levels } \\
\text { of sulfo- and glucuronide-conjugated RV } \\
\text { compounds. }\end{array}$ & [62] \\
\hline
\end{tabular}


Table 2. Cont

\begin{tabular}{|c|c|c|c|c|c|c|c|}
\hline $\begin{array}{c}\text { Metabolite } \\
\text { (form of RV) }\end{array}$ & Sample & Type of Study & (n) & Dose & $\begin{array}{c}\text { Participants' Health } \\
\text { Status }\end{array}$ & Effect & Ref. \\
\hline RV & Plasma & $\begin{array}{l}\text { Phase I and } \\
\text { randomized }\end{array}$ & 9 & $\begin{array}{c}1000 \mathrm{mg} / \text { day RV for } 28 \\
\text { days }\end{array}$ & Healthy & $\begin{array}{l}\text { RV was associated with an increase in the } \\
\text { number of circulating } \gamma \delta \mathrm{T} \text { cells and } \\
\text { regulatory T cells and higher plasma } \\
\text { antioxidant activity. }\end{array}$ & [63] \\
\hline $\begin{array}{l}\text { RV-3-O-sulfate, } \\
\text { RV-4'-O-glucuronide, } \\
\text { RV-3-O-glucuronide, }\end{array}$ & Plasma & Clinical trial & 40 & $\begin{array}{c}0.5,1.0,2.5, \text { or } 5.0 \mathrm{~g} / \text { day } \\
\text { RV for } 29 \text { days }\end{array}$ & Healthy & $\begin{array}{l}\text { Treatment with } 2.5 \mathrm{~g} \text { RV decreased IGF-1 } \\
\text { and IGFBP-3 levels in all volunteers; RV } \\
\text { might contribute to cancer chemoprevention. }\end{array}$ & [22] \\
\hline
\end{tabular}

A 340 : beta amyloid 40, ALT: alanine aminotransferase, AMPK: adenosine monophosphate-activated protein kinase, AST: aspartate aminotransferase, CRP: C reactive protein, $c$ R3G: cis-RV-3-O-glucuronide, cR3S: cis-RV-3-O-sulfate, cR4G: cis-RV-4'-O-glucuronide, $c$ R4S: cis-RV-4'-O-sulfate, CSF: cerebrospinal fluid, deoxy-Hb: deoxygenated Hb, DHR: Dihydroresveratrol, $\mathrm{Hb}$ : hemoglobin, IGF-1: insulin-like growth factor 1, IGFBP-3: insulin-like growth factor binding protein 3, IL-6: interleukin-6, MMP9: matrix metalloproteinase 9, PBMC: peripheral blood mononuclear cells, PGC1 $\alpha$ : peroxisome proliferator-activated receptor gamma coactivator 1 alpha, RV: resveratrol, SIRT1: sirtuin 1, T2D: type 2 diabetes, TNF- $\alpha$ : tumour necrosis factor alpha, TRM: total RV metabolites, $t$ R3G: trans-RV-3-O-glucuronide, $t$ R3S: trans-RV-3-O-sulfate, $t$ R4G: trans-RV-4' $-O$-glucuronide, $t$ R4S: trans-RV-4'- $O$-sulfate, $t$ RV: trans-RV, and $t$ RDS: trans-RV-disulfate. * Studies which identified resveratrol or some metabolite of resveratrol in plasma, urine, and/or feces. 


\section{Conclusions}

In this review, we have described the human clinical trials held in the last decade in which RV was determined in human plasma, urine, or feces. On the one hand, we conclude that the bioavailability and pharmacokinetics of RV depend on the doses ingested, the concomitant ingestion of food matrix, the particle size, the gut microbiota, and the circadian variation.

The results suggest that a repeated and moderate administration of RV is better than the administration of a single, higher dose. A safe and efficient dose is $1 \mathrm{~g}$ or more per day; however, $\mathrm{RV}$ intake is safe at a dose of up to $5 \mathrm{~g}$, although everyone may experience different adverse effects. Furthermore, the studies showed that RV excretion occurs mainly within the first four hours after ingestion.

On the other hand, RV could have positive effects such as improved antioxidant capacity and modulated neuroinflammation. However, there is disagreement about its positive effects in type 2 diabetes patients and on endothelial function, inflammation, and cardiovascular markers. Contrasting results may be due to the effects of the dose ingested, the gut microbiota status, the health status, and the bioavailability and pharmacokinetics of RV.

It is important to note that the contrasting effects of RV in the different works can be explained by factors such as the number of participants, health status of the gut microbiota, age, gender, lifestyle, dose, administration medium (with or without food), and type of administration (caplet, tablet, powder, gel caps, etc.). For this reason, future studies on RV effects should take into consideration these variables. In addition, further research should be conducted to study in more depth the mechanisms of action of RV in neurological diseases. This review supports the necessity to conduct of larger studies to further investigate the effects of RV on metabolism and neurological functions.

Author Contributions: Conceptualization, R.M.L.-R. and A.V.-Q.; writing, S.L.R.-G., E.P.L.-S., M.M.-M., C.E.S., A.T.-R., and A.V.-Q.; visualization, S.L.R.-G. and E.P.L.-S.; review, R.M.L.-R., A.V.-Q., and S.L.R.-G.

Funding: This work was supported in part by CICYT (AGL2016-75329-R), the Instituto de Salud Carlos III-ISCIII (CIBEROBN CB12/03/30020) from the Ministerio de Ciencia, Innovación y Universidades (AEI/FEDER, UE), and Generalitat de Catalunya (GC) 2017 SGR 196.

Acknowledgments: A.V.-Q. thanks the Ministry of Science, Innovation and Universities for the Ramon y Cajal contract. M.M.-M. thanks the Ministerio de Ciencia, Innovación y Universidades FPU17/00513. A.T.-R. was supported by a Juan de la Cierva Formación postdoctoral fellowship (FJCI-2016-28694) from the Ministerio de Economía, Industria y Competitividad.

Conflicts of Interest: R.M.L.-R. is receiving lecture fees from Cerveceros de España and lecture fees and travel support from Adventia. The other authors declare no conflict of interest.

\section{References}

1. Crozier, A.; Jaganath, I.B.; Clifford, M.N. Dietary phenolics: Chemistry, bioavailability and effects on health. Nat. Prod. Rep. 2009, 26, 1001-1043. [CrossRef] [PubMed]

2. Del Rio, D.; Rodriguez-Mateos, A.; Spencer, J.P.E.; Tognolini, M.; Borges, G.; Crozier, A. Dietary (Poly)phenolics in Human Health: Structures, Bioavailability, and Evidence of Protective Effects Against Chronic Diseases. Antioxid. Redox Signal. 2013, 18, 1818-1892. [CrossRef] [PubMed]

3. Stockley, C.; Teissedre, P.-L.; Boban, M.; Di Lorenzo, C.; Restani, P. Bioavailability of wine-derived phenolic compounds in humans: A review. Food Funct. 2012, 3, 995-1007. [CrossRef] [PubMed]

4. Martínez-Huélamo, M.; Vallverdú-Queralt, A.; Di Lecce, G.; Valderas-Martínez, P.; Tulipani, S.; Jáuregui, O.; Escribano-Ferrer, E.; Estruch, R.; Illan, M.; Lamuela-Raventós, R.M. Bioavailability of tomato polyphenols is enhanced by processing and fat addition: Evidence from a randomized feeding trial. Mol. Nutr. Food Res. 2016, 60, 1578-1589. [CrossRef] [PubMed]

5. Baur, J.A.; Pearson, K.J.; Price, N.L.; Jamieson, H.A.; Lerin, C.; Kalra, A.; Prabhu, V.V.; Allard, J.S.; Lopez-Lluch, G.; Lewis, K.; et al. Resveratrol improves health and survival of mice on a high-calorie diet. Nature 2006, 444, 337-342. [CrossRef] [PubMed] 
6. Miller, R.A.; Harrison, D.E.; Astle, C.M.; Baur, J.A.; Boyd, A.R.; de Cabo, R.; Fernandez, E.; Flurkey, K.; Javors, M.A.; Nelson, J.F.; et al. Rapamycin, but not resveratrol or simvastatin, extends life span of genetically heterogeneous mice. J. Gerontol. Ser. A Biol. Sci. Med. Sci. 2011, 66, 191-201. [CrossRef] [PubMed]

7. Pearson, K.J.; Baur, J.A.; Lewis, K.N.; Peshkin, L.; Price, N.L.; Labinskyy, N.; Swindell, W.R.; Kamara, D.; Minor, R.K.; Perez, E.; et al. Resveratrol delays age-related deterioration and mimics transcriptional aspects of dietary restriction without extending lifespan. Cell Metab. 2008, 8, 157-168. [CrossRef]

8. Barger, J.L.; Kayo, T.; Vann, J.M.; Arias, E.B.; Wang, J.; Hacker, T.A.; Wang, Y.; Raederstorff, D.; Morrow, J.D.; Leeuwenburgh, C.; et al. A low dose of dietary resveratrol partially mimics caloric restriction and retards aging parameters in mice. PLoS ONE 2008, 3, e2264. [CrossRef]

9. Baur, J.A.; Sinclair, D.A. Therapeutic potential of resveratrol: The in vivo evidence. Nat. Rev. Drug Discov. 2006, 5, 493-506. [CrossRef]

10. Poulsen, M.M.; Vestergaard, P.F.; Clasen, B.F.; Radko, Y.; Christensen, L.P.; Stødkilde-Jørgensen, H.; Møller, N.; Jessen, N.; Pedersen, S.B.; Jørgensen, J.O.L. High-dose resveratrol supplementation in obese men: An investigator-initiated, randomized, placebo-controlled clinical trial of substrate metabolism, insulin sensitivity, and body composition. Diabetes 2013, 62, 1186-1195. [CrossRef]

11. Ranney, A.; Petro, M.S. Resveratrol protects spatial learning in middle-aged C57BL/6 mice from effects of ethanol. Behav. Pharmacol. 2009, 20. [CrossRef] [PubMed]

12. Halliwell, B. Dietary polyphenols: Good, bad, or indifferent for your health? Cardiovasc. Res. 2007, 73, 341-347. [CrossRef] [PubMed]

13. Lagouge, M.; Argmann, C.; Gerhart-hines, Z.; Meziane, H.; Lerin, C.; Daussin, F.; Messadeq, N.; Milne, J.; Lambert, P.; Elliott, P.; et al. Resveratrol Improves mitochondrial function and protects against metabolic disease by activating SIRT1 and PGC-1 a. Cell 2006, 127, 1109-1122. [CrossRef] [PubMed]

14. Zang, M.; Xu, S.; Maitland-Toolan, K.A.; Zuccollo, A.; Hou, X.; Jiang, B.; Wierzbicki, M.; Verbeuren, T.J.; Cohen, R.A. Polyphenols stimulate AMP-activated protein kinase, lower lipids, and inhibit accelerated atherosclerosis in diabetic LDL receptor-deficient mice. Diabetes 2006, 55, 2180. [CrossRef] [PubMed]

15. Bordone, L.; Cohen, D.; Robinson, A.; Motta, M.C.; Van Veen, E.; Czopik, A.; Steele, A.D.; Crowe, H.; Marmor, S.; Luo, J.; et al. SIRT1 transgenic mice show phenotypes resembling calorie restriction. Aging Cell 2007, 6, 759-767. [CrossRef] [PubMed]

16. Buryanovskyy, L.; Fu, Y.; Boyd, M.; Ma, Y.; Hsieh, T.; Wu, J.M.; Zhang, Z. Crystal structure of quinone reductase 2 in complex with resveratrol. Biochemistry 2004, 43, 11417-11426. [CrossRef]

17. Soleas, G.J.; Yan, J.; Goldberg, D.M. Ultrasensitive assay for three polyphenols (catechin, quercetin and resveratrol) and their conjugates in biological fluids utilizing gas chromatography with mass selective detection. J. Chromatogr. B Biomed. Sci. Appl. 2001, 757, 161-172. [CrossRef]

18. Meng, X.; Maliakal, P.; Lu, H.; Lee, M.-J.; Yang, C.S. Urinary and plasma levels of resveratrol and quercetin in humans, mice, and rats after ingestion of pure compounds and grape juice. J. Agric. Food Chem. 2004, 52, 935-942. [CrossRef]

19. Zamora-Ros, R.; Urpí-Sardà, M.; Lamuela-Raventós, R.M.; Estruch, R.; Vázquez-Agell, M.; Serrano-Martínez, M.; Jaeger, W.; Andres-Lacueva, C. Diagnostic performance of urinary resveratrol metabolites as a biomarker of moderate wine consumption. Clin. Chem. 2006, 52, 1373-1380. [CrossRef]

20. Gambini, J.; Inglés, M.; Olaso, G.; Lopez-Grueso, R.; Bonet-Costa, V.; Gimeno-Mallench, L.; Mas-Bargues, C.; Abdelaziz, K.M.; Gomez-Cabrera, M.C.; Vina, J.; Borras, C. Properties of resveratrol: In vitro and in vivo studies about metabolism, bioavailability, and biological effects in animal models and humans. Oxid. Med. Cell. Longev. 2015, 2015, 1-13. [CrossRef]

21. Walle, T.; Hsieh, F.; DeLegge, M.H.; Oatis, J.E.J.; Walle, U.K. High absorption but very low bioavailability of oral resveratrol in humans. Drug Metab. Dispos. 2004, 32, 1377-1382. [CrossRef] [PubMed]

22. Brown, V.A.; Patel, K.R.; Viskaduraki, M.; Crowell, J.A.; Perloff, M.; Booth, T.D.; Vasilinin, G.; Sen, A.; Schinas, A.M.; Piccirilli, G.; et al. Repeat dose study of the cancer chemopreventive agent resveratrol in healthy volunteers: Safety, pharmacokinetics, and effect on the insulin-like growth factor axis. Cancer Res. 2010, 70, 9003-9011. [CrossRef] [PubMed]

23. Wightman, E.L.; Reay, J.L.; Haskell, C.F.; Williamson, G.; Dew, T.P.; Kennedy, D.O. Effects of resveratrol alone or in combination with piperine on cerebral blood flow parameters and cognitive performance in human subjects: A randomised, double-blind, placebo-controlled, cross-over investigation. Br. J. Nutr. 2014, 112, 203-213. [CrossRef] [PubMed] 
24. Turner, R.S.; Thomas, R.G.; Craft, S.; van Dyck, C.H.; Mintzer, J.; Reynolds, B.A.; Brewer, J.B.; Rissman, R.A.; Raman, R.; Aisen, P.S. A randomized, double-blind, placebo-controlled trial of resveratrol for Alzheimer disease. Neurology 2015, 85, 1383-1391. [CrossRef] [PubMed]

25. Yiu, E.M.; Tai, G.; Peverill, R.E.; Lee, K.J.; Croft, K.D.; Mori, T.A.; Scheiber-Mojdehkar, B.; Sturm, B.; Praschberger, M.; Vogel, A.P.; et al. An open-label trial in Friedreich ataxia suggests clinical benefit with high-dose resveratrol, without effect on frataxin levels. J. Neurol. 2015, 262, 1344-1353. [CrossRef] [PubMed]

26. Wong, R.H.X.; Howe, P.R.C.; Buckley, J.D.; Coates, A.M.; Kunz, I.; Berry, N.M. Acute resveratrol supplementation improves flow-mediated dilatation in overweight/obese individuals with mildly elevated blood pressure. Nutr. Metab. Cardiovasc. Dis. 2011, 21, 851-856. [CrossRef] [PubMed]

27. Wong, R.H.X.; Raederstorff, D.; Howe, P.R.C. Acute resveratrol consumption improves neurovascular coupling capacity in adults with type 2 diabetes mellitus. Nutrients 2016, 8, 425. [CrossRef]

28. Amri, A.; Chaumeil, J.C.; Sfar, S.; Charrueau, C. Administration of resveratrol: What formulation solutions to bioavailability limitations? J. Control. Release 2012, 158, 182-193. [CrossRef]

29. Amiot, M.J.; Romier, B.; Dao, T.A.; Fanciullino, R.; Ciccolini, J.; Burcelin, R.; Pechere, L.; Emond, C.; Savouret, J.; Seree, E. Optimization of trans -Resveratrol bioavailability for human therapy. Biochimie 2013, 95, 1233-1238. [CrossRef]

30. Rotches-Ribalta, M.; Urpi-Sarda, M.; Martí, M.M.; Reglero, G.; Andres-Lacueva, C. Resveratrol metabolic fingerprinting after acute and chronic intakes of a functional beverage in humans. Electrophoresis 2014, 35, 1637-1643. [CrossRef]

31. Rotches-Ribalta, M.; Andres-Lacueva, C.; Estruch, R.; Escribano, E.; Urpi-Sarda, M. Pharmacokinetics of resveratrol metabolic profile in healthy humans after moderate consumption of red wine and grape extract tablets. Pharmacol. Res. 2012, 66, 375-382. [CrossRef] [PubMed]

32. Hintz, R.; Johnson, K. The effect of particle size distribution on dissolution rate and oral absorption. Int. J. Pharm. 1989, 51, 9-17. [CrossRef]

33. Howells, L.M.; Berry, D.P.; Elliott, P.J.; Jacobson, E.W.; Hoffmann, E.; Hegarty, B.; Brown, K.; Steward, W.P.; Gescher, A.J. Phase I randomized, double-blind pilot study of micronized resveratrol (SRT501) in patients with hepatic metastases-Safety, pharmacokinetics, and pharmacodynamics. Cancer Prev. Res. 2011, 4, 1419-1425. [CrossRef] [PubMed]

34. La Porte, C.; Voduc, N.; Zhang, G.; Seguin, I.; Tardiff, D.; Singhal, N.; Cameron, D.W. Steady-State Pharmacokinetics and Tolerability of Trans-Resveratrol $2000 \mathrm{mg}$ Twice Daily with Food, Quercetin and Alcohol (Ethanol) in Healthy Human Subjects. Clin. Pharmacokinet. 2010, 49, 449-454. [CrossRef] [PubMed]

35. Vaz-da-Silva, M.; Loureiro, A.I.; Falcao, A.; Nunes, T.; Rocha, J.-F.; Fernandes-Lopes, C.; Soares, E.; Wright, L.; Almeida, L.; Soares-da-Silva, P. Effect of food on the pharmacokinetic profile of trans-resveratrol. Int. J. Clin. Pharmacol. Ther. 2008, 46, 564-570. [CrossRef] [PubMed]

36. Blanchard, O.L.; Friesenhahn, G.; Javors, M.A.; Smoliga, J.M. Development of a lozenge for oral transmucosal delivery of trans-resveratrol in humans: Proof of concept. PLoS ONE 2014, 9, e90131. [CrossRef] [PubMed]

37. Draijer, R.; Van Dorsten, F.A.; Zebregs, Y.E.; Hollebrands, B.; Peters, S.; Duchateau, G.S.; Grün, C.H. Impact of proteins on the uptake, distribution, and excretion of phenolics in the human body. Nutrients 2016, 8, 814 . [CrossRef]

38. Rotches-Ribalta, M.; Urpi-Sarda, M.; Llorach, R.; Boto-Ordoñez, M.; Jauregui, O.; Chiva-Blanch, G.; Perez-Garcia, L.; Jaeger, W.; Guillen, M.; Corella, D.; et al. Gut and microbial resveratrol metabolite profiling after moderate long-term consumption of red wine versus dealcoholized red wine in humans by an optimized ultra-high-pressure liquid chromatography tandem mass spectrometry method. J. Chromatogr. A 2012, 1265, 105-113. [CrossRef]

39. Almeida, L.; Vaz-da-Silva, M.; Falcão, A.; Soares, E.; Costa, R.; Loureiro, A.I.; Fernandes-Lopes, C.; Rocha, J.; Nunes, T.; Wright, L.; Soares-da-Silva, P. Pharmacokinetic and safety profile of trans-resveratrol in a rising multiple-dose study in healthy volunteers. Mol. Nutr. Food Res. 2009, 53, 7-15. [CrossRef]

40. Bode, L.M.; Bunzel, D.; Huch, M.; Cho, G.; Ruhland, D.; Bunzel, M.; Bub, A.; Franz, C.M.A.P.; Kulling, S.E. In vivo and in vitro metabolism of trans -resveratrol by human gut. Am. J. Clin. Nutr. 2013, 97, 295-309. [CrossRef]

41. Most, J.; Penders, J.; Lucchesi, M.; Goossens, G.H.; Blaak, E.E. Gut microbiota composition in relation to the metabolic response to 12-week combined polyphenol supplementation in overweight men and women. Eur. J. Clin. Nutr. 2017, 71, 1040-1045. [CrossRef] [PubMed] 
42. Chachay, V.S.; Macdonald, G.A.; Martin, J.H.; Whitehead, J.P.; O’Moore-Sullivan, T.M.; Lee, P.; Franklin, M.; Klein, K.; Taylor, P.J.; Ferguson, M.; et al. Resveratrol Does Not Benefit Patients With Nonalcoholic Fatty Liver Disease. Clin. Gastroenterol. Hepatol. 2014, 12, 2092-2103.e6. [CrossRef] [PubMed]

43. Boocock, D.J.; Faust, G.E.S.; Patel, K.R.; Schinas, A.M.; Brown, V.A.; Ducharme, M.P.; Booth, T.D.; Crowell, J.A.; Perloff, M.; Gescher, A.J.; et al. Phase i dose escalation pharmacokinetic study in healthy volunteers of resveratrol, a potential cancer chemopreventive agent. Cancer Epidemiol. Biomark. Prev. 2007, 16, 1246-1253. [CrossRef]

44. Yoshino, J.; Conte, C.; Fontana, L.; Mittendorfer, B.; Imai, S.I.; Schechtman, K.B.; Gu, C.; Kunz, I.; Fanelli, F.R.; Patterson, B.W.; et al. Resveratrol supplementation does not improve metabolic function in nonobese women with normal glucose tolerance. Cell Metab. 2012, 16, 658-664. [CrossRef] [PubMed]

45. Crandall, J.P.; Oram, V.; Trandafirescu, G.; Reid, M.; Kishore, P.; Hawkins, M.; Cohen, H.W.; Barzilai, N. Pilot study of resveratrol in older adults with impaired glucose tolerance. J. Gerontol. Ser. A 2012, 67, 1307-1312. [CrossRef] [PubMed]

46. Azachi, M.; Yatuv, R.; Katz, A.; Hagay, Y.; Danon, A. A novel red grape cells complex: Health effects and bioavailability of natural resveratrol. Int. J. Food Sci. Nutr. 2014, 65, 848-855. [CrossRef]

47. Moussa, C.; Hebron, M.; Huang, X.; Ahn, J.; Rissman, R.A.; Aisen, P.S.; Turner, R.S. Resveratrol regulates neuro-inflammation and induces adaptive immunity in Alzheimer's disease. J. Neuroinflamm. 2017, $14,1$. [CrossRef] [PubMed]

48. Kennedy, D.O.; Wightman, E.L.; Reay, J.L.; Lietz, G.; Okello, E.J.; Wilde, A.; Haskell, C.F. Effects of resveratrol on cerebral blood flow variables and cognitive performance in humans: A double-blind, placebo-controlled, crossover. Am. J. Clin. Nutr. 2010, 91, 1590-1597. [CrossRef]

49. Bakker, G.C.M.; Van Erk, M.J.; Pellis, L.; Wopereis, S.; Rubingh, C.M.; Cnubben, N.H.P.; Kooistra, T.; Van Ommen, B.; Hendriks, H.F.J. An antiinflammatory dietary mix modulates inflammation and oxidative and metabolic stress in overweight men: A nutrigenomics approach 1-4. Am. J. Clin. Nutr. 2010, 91, 1044-1059. [CrossRef] [PubMed]

50. Brasnyó, P.; Molnár, G.A.; Mohás, M.; Markó, L.; Laczy, B.; Cseh, J.; Mikolás, E.; Szijártó, I.A.; Mérei, Á.; Halmai, R.; Mészáros, L.G.; et al. Resveratrol improves insulin sensitivity, reduces oxidative stress and activates the Akt pathway in type 2 diabetic patients. Br. J. Nutr. 2011, 106, 383-389. [CrossRef] [PubMed]

51. Dash, S.; Xiao, C.; Morgantini, C.; Szeto, L.; Lewis, G.F. High-dose resveratrol treatment for 2 weeks inhibits intestinal and hepatic lipoprotein production in overweight/obese men. Arterioscler. Thromb. Vasc. Biol. 2013, 33, 2895-2901. [CrossRef] [PubMed]

52. Timmers, S.; de Ligt, M.; Phielix, E.; van de Weijer, T.; Hansen, J.; Moonen-Kornips, E.; Schaart, G.; Kunz, I.; Hesselink, M.K.C.; Schrauwen-Hinderling, V.B.; et al. Resveratrol as add-on therapy in subjects with well-controlled type 2 diabetes: A randomized controlled trial. Diabetes Care 2016, 39, 2211-2217. [CrossRef] [PubMed]

53. Knop, F.K.; Konings, E.; Timmers, S.; Schrauwen, P.; Holst, J.J.; Blaak, E.E. Thirty days of resveratrol supplementation does not affect postprandial incretin hormone responses, but suppresses postprandial glucagon in obese subjects. Diabet. Med. 2013, 30, 1214-1218. [CrossRef] [PubMed]

54. Grifantini, K. Understanding pathways of calorie restriction: A way to prevent cancer? J. Natl. Cancer Inst. 2008, 100, 619-621. [CrossRef] [PubMed]

55. Caramori, P.R.; Zago, A.J. Endothelial dysfunction and coronary artery disease. Arq. Bras. Cardiol. 2000, 75, 163-182. [CrossRef] [PubMed]

56. Grassi, G.; Seravalle, G.; Scopelliti, F.; Dell’Oro, R.; Fattori, L.; Quarti-Trevano, F.; Brambilla, G.; Schiffrin, E.L.; Mancia, G. Structural and functional alterations of subcutaneous small resistance arteries in severe human obesity. Obesity 2010, 18, 92-98. [CrossRef] [PubMed]

57. Zamora-Ros, R.; Urpi-Sarda, M.; Lamuela-Raventós, R.M.; Martínez-González, M.Á.; Salas-Salvadó, J.; Arós, F.; Fitó, M.; Lapetra, J.; Estruch, R.; Andres-Lacueva, C. High urinary levels of resveratrol metabolites are associated with a reduction in the prevalence of cardiovascular risk factors in high-risk patients. Pharmacol. Res. 2012, 65, 615-620. [CrossRef]

58. Van Der Made, S.M.; Plat, J.; Mensink, R.P. Resveratrol does not influence metabolic risk markers related to cardiovascular health in overweight and slightly obese subjects: A randomized, placebo-controlled crossover trial. PLoS ONE 2015, 10, 1-13. [CrossRef] 
59. Van der Made, S.M.; Plat, J.; Mensink, R.P. Trans-resveratrol supplementation and endothelial function during the fasting and postprandial phase: A randomized placebo-controlled trial in overweight and slightly obese participants. Nutrients 2017, 9, 596. [CrossRef]

60. Timmers, S.; Konings, E.; Bilet, L.; Houtkooper, R.H.; van de Weijer, T.; Goossens, G.H.; Hoeks, J.; van der Krieken, S.; Ryu, D.; Kersten, S.; et al. Calorie restriction-like effects of 30 days of resveratrol supplementation on energy metabolism and metabolic profile in obese humans. Cell Metab. 2011, 14, 612-622. [CrossRef]

61. Most, J.; Timmers, S.; Warnke, I.; Jocken, J.W.; van Boekschoten, M.; de Groot, P.; Bendik, I.; Schrauwen, P.; Goossens, G.H.; Blaak, E.E. Combined epigallocatechin-3-gallate and resveratrol supplementation for $12 \mathrm{wk}$ increases mitochondrial capacity and fat oxidation, but not insulin sensitivity, in obese humans: A randomized controlled trial. Am. J. Clin. Nutr. 2016, 104, 215-227. [CrossRef] [PubMed]

62. Gualdoni, G.A.; Kovarik, J.J.; Hofer, J.; Dose, F.; Doberer, D.; Steinberger, P.; Wolzt, M.; Zlabinger, G.J. Resveratrol enhances TNF- $\alpha$ production in human monocytes upon bacterial stimulation. Biochim. Biophys. Acta Gen. Subj. 2014, 1840, 95-105. [CrossRef] [PubMed]

63. Espinoza, J.L.; Trung, L.Q.; Inaoka, P.T.; Yamada, K.; An, D.T.; Mizuno, S.; Nakao, S.; Takami, A. The Repeated Administration of Resveratrol Has Measurable Effects on Circulating T-Cell Subsets in Humans. Oxid. Med. Cell. Longev. 2017, 2017, 6781872. [CrossRef] [PubMed]

64. Lin, C.; Sun, X.; Lin, A. Supplementation with high-dose trans-resveratrol improves ultrafiltration in peritoneal dialysis patients: A prospective, randomized, double-blind study. Ren. Fail. 2016, 38, $214-221$. [CrossRef] [PubMed]

(C) 2018 by the authors. Licensee MDPI, Basel, Switzerland. This article is an open access article distributed under the terms and conditions of the Creative Commons Attribution (CC BY) license (http://creativecommons.org/licenses/by/4.0/). 